\title{
Prospects for developing an early maturing variety of Winged Bean (Psophocarpus tetragonolobus) in Bogor, Indonesia
}

\author{
GRAHAM E. EAGLETON \\ Department of Planning, Building 15, Ministry of Agriculture, Livestock and Irrigation, Nay Pyi Taw, Myanmar. \\ Tel. +95-98-93738406. Permanent address: 23 Mulhall Street, Wagstaffe, NSW 2257, Australia. ^email: grahameagleton@gmail.com
}

Manuscript received: 2 September 2019. Revision accepted: 9 October 2019.

\begin{abstract}
Eagleton GE. 2019. Prospects for developing an early maturing variety of Winged Bean (Psophocarpus tetragonolobus) in Bogor, Indonesia. Biodiversitas 20: 3142-3152. To investigate the possibility of producing a more convenient, early-maturing cultivar of winged bean for vegetable growers in West Java, an early flowering accession introduced from Singapore Botanic Gardens ('Singha', the female parent) was crossed with a vegetatively vigorous, late-maturing, local winged bean accession ('Bogor', the male parent). The phenology and general performance of plants of the parental accessions and of their F1 and F2 hybrid generations were compared in the plant nursery of the Bogor Botanic Gardens ( $\left.6^{0} 36^{\prime} \mathrm{S}, 106^{0} 48^{\prime} \mathrm{E}\right)$ in three successive experiments over ten months. In each of the three experimental plantings, the mean number of days to first open flower for the Bogor variety (B) was more than 40 days later than for the Singha variety (S). There was no significant difference in the average number of days to first open flower between F1 plants (S x B) and Singha plants in the first two experiments, but in the third experiment the F1 plants flowered 23 days later than the Singha parent. The phenological development of all genotypes, but especially the Bogor variety, appeared to be retarded by long daylengths. Out of nineteen F2 plants included in the third experiment, six flowered at least as early as the average of the early flowering Singha parent, nine overlapped the distribution for the F1 plants, while only two were as late as the Bogor parent. It was inferred that flowering time in this particular cross was influenced as much by dominance effects as by additive genetic effects, with early flowering dominant to late flowering. Plants in the first two experiments were severely affected by collar-rot disease with no difference between genotypes. In the third experiment, planted in a potting-mix in poly-bags that avoided the collar-rot, all plants of the Singha and most plants of the F1 and F2 generations became infected by false-rust disease Synchytrium psophocarpi (Rac.) Baumann, whereas none of the Bogor plants exhibited symptoms of false-rust. The results support the finding in a previous study by Aminah-Lubis and Sastrapradja (1981) that the resistance to false rust disease found in Bogor winged bean varieties is conferred by genes that are recessive to genes conferring susceptibility to the disease. This investigation has implications for breeding improved varieties of vegetable winged bean and for understanding the evolution of winged bean as a crop.
\end{abstract}

Keywords: False-rust, phenology, Psophocarpus tetragonolobus, West Java, winged bean

\section{INTRODUCTION}

Winged bean (Psophocarpus tetragonolobus (L.) DC.), known in Indonesian as 'kacang kecipir' and in Sundanese as 'jaat', is a useful household vegetable in Java and the rest of tropical Asia (Sastrapradja and Aminah-Lubis 1975; Thompson and Haryono 1980; Khan 1992; Lepcha et al. 2017; Tanzi et al. 2019a). The green vegetable pods are sold in small quantities in village markets in Java and from time to time appear in metropolitan supermarket shelves, packaged in plastic wrap alongside common bean ('kacang buncis', Phaseolus vulgaris L.) and yardlong bean ('kacang panjang', Vigna unguiculata (L.) Walp. ssp. sesquipedalis Verdc.).

From the producer's point of view, one factor which limits winged bean's competitiveness is that it takes almost twice as long to produce first marketable green pods (13-14 weeks; Wong 1980) as its two rival vegetable bean species (8-9 weeks). This is especially so in the case of the late maturing, climbing cultivars commonly grown in West Java, the pods of which are sold in the fresh markets of Bogor (Sastrapradja et al. 1978). Previous research has shown that the usual varieties of winged bean planted in Java yield well and have genetic resistance to diseases like false rust (Synchytrium psophocarpi (Rac.) Gäumann) and yellow-mosaic virus that limit the productivity of susceptible varieties (Thompson and Haryono 1979; Aminah-Lubis and Sastrapradja 1981; Parman and Thompson 1981). Despite these advantages, the latematuring characteristics of the Bogor variety make it more expensive to produce, because farmers must wait up to one extra month for the trellised plants to produce harvestable pods compared to the other commercial bean species (Figure 1).

Thus, a small project was undertaken in 2016-17 to see whether early maturity could be introduced into a Bogor variety by out-crossing it to an early maturing variety (of uncertain origin) introduced from the Singapore Botanic Gardens. The introduced variety, named 'Singha' for the sake of this paper, had been shown in a preliminary experiment to mature much earlier than a locally purchased Bogor market variety. In that preliminary experiment, F1 seed was produced by crossing plants of the Bogor variety as male parents to a single Singha plant as female parent, using a modification of the technique described by Erskine and Bala (1976) and Tanzi et al. (2019 b). This paper reports on a comparison of the maturity characteristics and general performance between the Bogor and Singha varieties and their $\mathrm{F} 1$ and $\mathrm{F} 2$ progeny. 

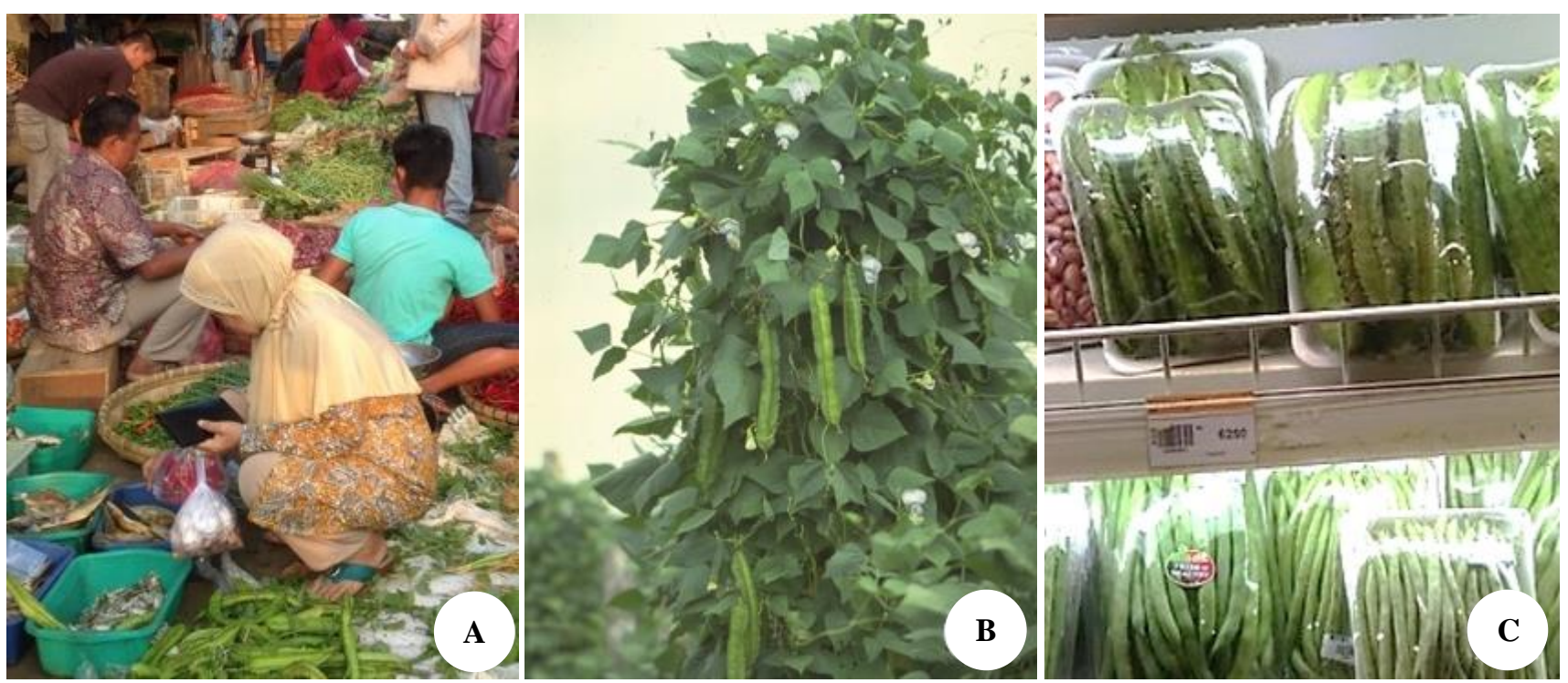

Figure 1. Winged bean remains a minor household vegetable in West Java (A) pods on sale at Bogor wet market (B) climbing growth habit (C) occasionally, winged beans appear on sale in suburban supermarkets

\section{MATERIALS AND METHODS}

\section{Study site}

Between June 2106 and March 2017, three overlapping plantings (Experiments 1,2 and 3) of the winged bean varieties and their hybrid progeny were carried out in an open nursery area of the Centre for Plant Conservation, Bogor Botanic Gardens $\left(6^{0} 36^{\prime} \mathrm{S}, 106^{\circ} 48^{\prime} \mathrm{E}\right.$, altitude $260 \mathrm{~m}$ asl). The soil of the planting area was a poorly drained, compacted latosol.

Bogor has a tropical rainforest climate and is renown as one of the rainiest locations in the Indonesian archipelago. Annual precipitation usually exceeds $3500 \mathrm{~mm}$, and even in the driest quarter of the year, from June to August, rainfall exceeds $200 \mathrm{~mm}$ per month. The annual average humidity is around $70 \%$, and while monthly average temperature varies little from $24.7^{\circ} \mathrm{C}$ in January to $25.6^{\circ} \mathrm{C}$ in September, diurnal variation is quite high, approaching $10^{\circ} \mathrm{C}$ on average (Climate-Data 2019). Daylength ranges from around 11.6 hours in late-June to around 12.3 hours in late-December.

In the first experiment, planted in June 2016, severe collar-rot disease led to the early death of $50 \%$ of the plants within three months. As a result, the second experiment of similar design but with more intensive plant protection measures was planted in August. However, collar-rot afflicted that experiment also. So, a third experiment, this time sown in a potting soil mix in poly-bags, was planted in November. The details of methods used for each experiment are described here.

\section{Experiment 1}

The three experiments aimed to compare the phenology and general performance of $\mathrm{F} 1$ plants with that of their two parent varieties. 'Bogor' and 'Singha'. In Experiment 1, a completely randomized design was employed with ten replications of the three 'treatments': i.e. Bogor (B), Singha (S), and the F1 hybrid of S (female parent) x B (male parents).

On 21 June 2016, two F1 seed from each of six pods were planted out along with seed of the Bogor variety and seed of the Singha variety into separate petri dishes containing moistened tissue paper. On day 8 (29 June) after all seeds had imbibed water and begun to germinate, the sprouted seeds were transferred as individual plants to small pots containing a 1:1:1 mixture of compost: sandy loam: cocoa-peat/charcoaled rice-husk. On day 34, emerged seedlings were transplanted into the prepared garden bed of the nursery area. The 30 seedlings (ten replicate plants of each of the three genotypes) were randomly allocated to the garden; six rows of five plants at an inter-plant spacing of $75 \mathrm{~cm} \mathrm{X} 75 \mathrm{~cm}$. Each plant was provided with separate staking support, consisting of a tripod of split bamboo tied together. Identical management (in terms of NPK fertilizer applications and pest and disease control) was applied to each plant.

Beginning around day 49 (9 August), plants began to die. Termites, observed among the roots of all affected plants, were first thought to be the primary cause of the plant losses, and granular carbofuran (Furadan $\circledast$ ) was applied to the base of the surviving plants. Closer inspection revealed symptoms of collar-rot disease. Application of mancozeb fungicide (Dithane ${ }_{\circledast}$ ) as a spray to stems of plants already exhibiting symptoms of collar-rot did not prevent the death of seedlings. However, in general, those plants that survived the seedling stage and developed thickened stems did not succumb to the disease.

The following observations were recorded during the experiment: (i) Number of surviving plants on day 49 (9 August), day 63 (23 August) and day 75 (4 September). (ii) Number of days from the day of planting (21 June) to first open flower for all surviving plants. (iii) Number of leaf 
nodes (excluding the first, unifoliate leaves) to the position of the first open flowering inflorescence. (iv) Number of days from planting (21 June) to the last open-flower, up to termination of the experiment on day 225 (1 February 2017). (v) Total number of flowers that opened per plant up to day 225. (vii) Number of days from planting (21 June) to the first fully mature pod. (viii) Number of mature pods per plant up to day 225. (ix) Average length $(\mathrm{cm})$ of all mature pods for each plant. (x) The total number and weight $(\mathrm{g})$ of mature seeds harvested per plant up to day 225 (1 February). (xi) Weight (g) of 100 seeds.

\section{Experiment 2}

All the dead plants from Experiment 1 were removed, and their plot positions were weeded and dug up into mounds, with granular carbofuran $\left(\right.$ Furadan $\left._{\circledast}\right)$ applied on 23 August ready for replanting. The bamboo stakes were replaced for these 18 plots.

Seed for Experiment 2 was soaked on (23 August) ready for the replanting. On day 4 of this experiment (27 August), the just-germinating seeds were planted into the hillocks. The design for Experiment 2 was a completely randomized design of six Bogor (B) plants, six Singha (S) plants and six F1 ( $\left.\begin{array}{lll}S & \mathrm{~B}\end{array}\right)$ plants. The insecticide deltamethrin (Decis ${ }_{\circledast}$ ) and fungicide mancozeb (Dithane ${ }_{\circledast}$ ) were sprayed immediately on appearance of the first trifoliate leaves, and a regime of spraying was maintained about every three weeks for the duration of the experiment. Despite this, the rate of plant death was similar to that experienced in Experiment 1.

The following observations were recorded: (i) Number of surviving plants on day 39 of Experiment 2 (1 October 2016) and on day131 (1 January 2017). (ii) Number of days from the day of planting (23 August) to first opened flower for all surviving plants. (iii) Number of days to the last observed open flower up to termination of the experiment on day 165 (4 February 2017). (iv) Total number of flowers that opened per plant up to day 165. (v) Number of days from planting (23 August) to the first fully mature pod.

\section{Experiment 3}

Ten seeds each of Bogor, Singha and the F1 ( $\mathrm{S} \times \mathrm{B})$, along with twenty F2 seeds harvested from five F1 plants in Experiment 1, were sprouted in petri dishes containing moistened tissue paper on 3 November 2016. Then, on day 4 of Experiment 3 (7 November), seven sprouting seeds of Bogor, seven of Singha, seven of F1, and nineteen of F2 were randomly allocated to forty 10-liter poly-bags each containing a 1:1:1 mixture of compost: sandy loam: cocoapeat/charcoaled rice husk. Carbofuran (Furadan ${ }_{\circledast}$ ) was applied to each bag along with NPK fertilizer. In this experiment, no symptoms of collar-rot were observed despite heavy, almost daily, rainfall, and only one plant was lost before the eventual termination of the experiment on day 133 (16 March 2017). On the other hand, beginning around day 93 (4 February), symptoms of false-rust disease (caused by Synchytrium psophocarpi (Rac.) Gäumann) appeared among plants of the Singha variety and its hybrid offspring. Despite weekly spray applications of mancozeb fungicide (Dithane ${ }_{\circledast}$ ), this disease gained in significance throughout the experiment but did not appear to have greatly affected reproductive development up to day 133 .

The following observations were recorded for this experiment: (i) Number of surviving plants at termination of the experiment on day 133 (16 March 2017). (ii) Number of plants in each genotype class that had flowered up to day 118 (1 March). (iii) The number of days from day 1 (3 November) to first opened flower for all plants up to termination of the experiment on day 133. (iv) The number of plants in each genotype class with symptoms of falserust disease on days 93, 97, 116, 119, 121, 123, 126, 133 (4 February 2017 to 16 March 2017).

\section{Analysis}

Single-factor analyses of variance were carried out to test for the significance of differences in quantitative traits between the genotype classes. Where only two genotype classes were being compared, t-tests were performed based on assumptions either of equal variance or unequal variance, depending on the particular variables under consideration. Tests of significance for treatment effects on variables within the same experiment were performed at the 5\% level of significance corrected for the False Discovery Rate (FDR) by a Bonferonni procedure (Benjamini and Hochberg 1995). All tests of significance and calculations of descriptive statistics (means and standard errors of the mean) were carried out in Microsoft Excel $_{\circledast}$. Chi-squared tests of significance were conducted to test the adequacy of hypothesized genetic models for explaining observed discontinuities in some plant characters; namely, flower color, number of days to first open flower, and susceptibility to false rust.

\section{RESULTS AND DISCUSSION}

\section{Verification of the effectiveness of hybridization}

At the time of planting the experiments, it was not known if the six pods of supposed F1 seed were, in fact, the products of successful hybridization. This was clarified at the time of flowering and mature seed formation. The Bogor parent plants all had green calices, blue flowers and sizeable brown seed while the Singha variety had green calices, white flowers and small white seed. All F1 plants, without exception, were found to have purplish calices, distinctive mauve colored flowers and mottled, mediumsized seed (Figure 2). In Experiment 3, the ratio of white, to mauve, to blue flowering plants among the F2 plants was observed to be 7: 9: 2. A Chi-squared test indicated no significant difference $(\mathrm{p}<0.05)$ from a ratio of $1: 2$ : 1 , expected under a single gene model with incomplete dominance. On the other hand, a 7: 6: 3 two-locus model with epistasis gave just as adequate a fit to the data (no significant difference from model at $\mathrm{p}<0.05$ ). Thus, further investigations, with larger sample sizes and possibly including back-crosses, would be required to elucidate the true nature of the genetic control of flower color in the cross between Bogor and Singha. Molecular markers could supplement gross phenotypic characters in determining the veracity of such crosses (Wong et al. 2017; Tanzi et al. 2019b). 

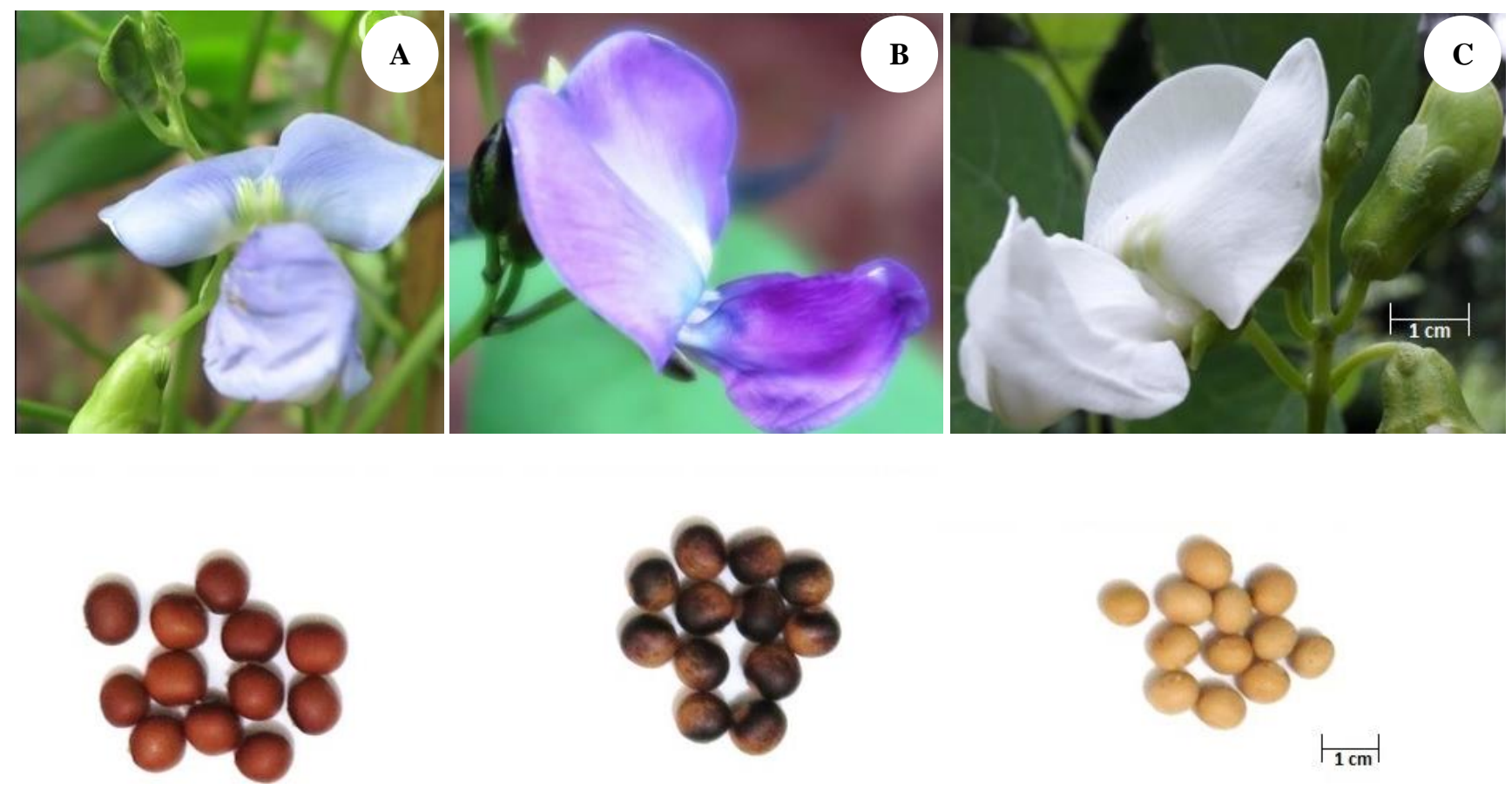

Figure 2. Simple marker characteristics that distinguished the F1 winged bean hybrid plants from its parents: calyx color, flower color, color of seed coat and seed size of (A) Bogor parent, (B) F1 hybrid, and (C) Singha parent

\section{Experiment 1}

By the time the first plants had begun to flower on day 63 (23 August), more than 50\% of the plants had died. These plants exhibited symptoms of collar-rot, though the specific causal organisms were not identified. The fact that no plants in the poly-bag soil of Experiment 3 exhibited symptoms of the collar-rot (see below) was strong evidence that the cause of the disease in Experiments 1 and 2 was indeed a soil-borne organism residing in the soils of the nursery garden. Such root- and collar-rots have been reported elsewhere in the literature (Price and Munro 1978; Reddy 2015) and have most usually been associated with wet, poorly drained fields. Across Experiments 1 and 2, there was little evidence of any varietal differences in susceptibility to collar-rot: Bogor, Singha and the F1 hybrid plants were similarly susceptible, as indicated by survival percentage over time in the three genotypic classes (Table 1 and Table 4).

The phenology of those plants that did survive the peak of the collar-rot disease is summarized in Table 2. By the termination of the experiment on 1 February 2017, all surviving plants had reached at least the stage of first open flower, but plants of the Bogor variety were markedly later to flower than plants of the Singha variety and of the F1 hybrids. There was no significant difference between Singha plants and the F1 hybrid plants in either the number of days to first flower or the number of nodes to the position of the first flower. In the case of the Bogor plants, flowering occurred so high in the canopy that the number of nodes to first flower could only be estimated but was at least 15 nodes. The Singha variety and the F1 hybrid plants produced their first mature pods significantly before plants of the Bogor variety. Plants of the Singha variety had a much shorter duration of flowering than the Bogor variety and the F1 hybrids. For this reason, the Singha variety had fewer pods per plant than Bogor and the F1 hybrid, though due to the very high coefficient of variation (81\%) the difference did not reach significance.

There was no statistically significant difference between genotypes in the mean pod length and the mean number of seeds in the pods (Table 3). The correlation between pod length and seed number per pod across genotypes $(r=0.66)$ was highly significant; and there was no significant difference between genotypes in the degree of correlation. The high coefficient of variation (88\%) for total seed weight per plant up to the time of termination of the experiment masked a likely lower seed yield in Singha compared to Bogor and the F1 hybrid genotypes. Singha plants had smaller seeds than F1 plants, which in turn were smaller than were seeds of the Bogor variety (Figure 2).

Table 1. Plant survival on 9 August, 23 August and 24 September in plants of Bogor (B), Singha (S) and F1 (S x B) genotypes planted on 21 June 2016.

\begin{tabular}{lccc}
\hline & Day 49 & $\begin{array}{c}\text { \% plant survival } \\
\text { Day 63 }\end{array}$ & Day 95 \\
\hline Bogor & 100 & 70 & 40 \\
Singha & 80 & 30 & 30 \\
F1 S x B & 90 & 80 & 50 \\
\hline
\end{tabular}


Table 2. The phenology of plants of Bogor (B), Singha (S) and F1 (S x B) genotypes in Experiment 1; flower and mature pod development.

\begin{tabular}{lllllll}
\hline & $\begin{array}{c}\text { Number of days } \\
\text { to first open } \\
\text { flower }\end{array}$ & $\begin{array}{c}\text { Node of } \\
\text { first open flower }\end{array}$ & $\begin{array}{c}\text { Duration } \\
\text { of flowering } \\
\text { (days) }\end{array}$ & $\begin{array}{c}\text { Total } \\
\text { number of } \\
\text { flowers / plant }\end{array}$ & $\begin{array}{c}\text { Number of days } \\
\text { to first } \\
\text { mature pod }\end{array}$ & $\begin{array}{c}\text { Number of } \\
\text { mature } \\
\text { pods / plant }\end{array}$ \\
\hline Bogor & $122.8 \pm 34.4^{\mathrm{a}}$ & $>15 \pm 0.0^{\mathrm{a}}$ & $62.7 \pm 11.7^{\mathrm{a}}$ & $39.5 \pm 24.3^{\mathrm{a}}$ & $190.3 \pm 25.9^{\mathrm{a}}$ & $8.5 \pm 7.3^{\mathrm{a}}$ \\
Singha & $79.7 \pm 23.9^{\mathrm{b}}$ & $7.3 \pm 1.2^{\mathrm{b}}$ & $11.0 \pm 1.0^{\mathrm{b}}$ & $11.0 \pm 5.3^{\mathrm{a}}$ & $121.0 \pm 2.8^{\mathrm{b}}$ & $4.3 \pm 3.8^{\mathrm{a}}$ \\
S x B & $70.8 \pm 5.4^{\mathrm{b}}$ & $10.8 \pm 2.9^{\mathrm{b}}$ & $41.4 \pm 18.9^{\mathrm{a}}$ & $16.4 \pm 12.8^{\mathrm{a}}$ & $142.4 \pm 15.6^{\mathrm{b}}$ & $7.6 \pm 5.2^{\mathrm{a}}$ \\
\hline
\end{tabular}

Note: Values are the means \pm standard deviations; within a column, values followed by the same letter do not differ significantly $(\mathrm{P}<0.05)$

Table 3. Characteristics of pods and seeds formed by plants of Bogor (B), Singha (S) and F1 (S x B) genotypes in Experiment 1.

\begin{tabular}{|c|c|c|c|c|}
\hline & $\begin{array}{l}\text { Pod length } \\
\text { (cm) }\end{array}$ & $\begin{array}{c}\text { Number of seed } \\
\text { per pod }\end{array}$ & $\begin{array}{c}\text { Total seed weight } \\
\text { per plant (g) }\end{array}$ & $\begin{array}{c}\text { Weight of } 100 \text { seeds } \\
\text { (g) }\end{array}$ \\
\hline Bogor & $20.1 \pm 3.1^{\mathrm{a}}$ & $11.9 \pm 3.2^{\mathrm{a}}$ & $34.1 \pm 29.4^{\mathrm{a}}$ & $48.3 \pm 2.0^{\mathrm{a}}$ \\
\hline Singha & $16.1 \pm 3.2^{\mathrm{a}}$ & $11.9 \pm 3.2^{\mathrm{a}}$ & $11.3 \pm 9.6^{\mathrm{a}}$ & $16.5-c$ \\
\hline $\mathrm{S} \times \mathrm{B}$ & $19.2 \pm 3.1^{\mathrm{a}}$ & $11.0 \pm 3.1^{\mathrm{a}}$ & $26.7 \pm 20.6^{\mathrm{a}}$ & $34.9 \pm 2.9^{b}$ \\
\hline
\end{tabular}

Note: Values are the means \pm standard deviations; within a column, values followed by the same letters do not differ significantly $(\mathrm{P}<0.05)$

Table 4. Plant survival and phenology of plants of Bogor (B), Singha (S) and F1 (S x B) genotypes in Experiment 2.

\begin{tabular}{lcccccc}
\hline & $\begin{array}{c}\text { \% plant survival } \\
\text { Day 39 } \\
\text { 1 Oct }\end{array}$ & $\begin{array}{c}\text { Day 131 } \\
\text { 1 Jan }\end{array}$ & $\begin{array}{c}\text { Number of days } \\
\text { to first open flower }\end{array}$ & $\begin{array}{c}\text { Duration } \\
\text { of flowering } \\
\text { (days) }\end{array}$ & $\begin{array}{c}\text { Total } \\
\text { number of } \\
\text { flowers / plant }\end{array}$ & $\begin{array}{c}\text { Number of days to first } \\
\text { mature pod }\end{array}$ \\
\hline Bogor & 83 & 33 & $>165.0 \pm-^{\mathrm{a}}$ & - & - & - \\
Singha & 83 & 67 & $82.8 \pm 19.7^{\mathrm{b}}$ & $22.8 \pm 9.1^{\mathrm{a}}$ & $13.6 \pm 4.7^{\mathrm{a}}$ & $135.6 \pm 20.0^{\mathrm{a}}$ \\
S x B & 67 & 50 & $88.7 \pm 3.6^{\mathrm{b}}$ & $23.0 \pm 2.6^{\mathrm{a}}$ & $17.0 \pm 9.2^{\mathrm{a}}$ & $147.0 \pm 5.3^{\mathrm{a}}$ \\
\hline
\end{tabular}

Note: Values are the means \pm standard deviations; within a column, values followed by the same letters do not differ significantly $(\mathrm{P}<0.05)$.

Table 5. Plant survival and phenology of plants of Bogor (B), Singha (S) and F1 (S x B) genotypes in Experiment 3.

\begin{tabular}{lccc}
\hline Treatment & $\begin{array}{c}\text { \% plant } \\
\text { survival }\end{array}$ & $\begin{array}{c}\text { \% plants } \\
\text { that } \\
\text { flowered by } \\
\text { 1 Mar }\end{array}$ & $\begin{array}{c}\text { Days to first open } \\
\text { flower }\end{array}$ \\
\hline Bogor (B) & 100 & 0 & $>130.3 \pm 3.5^{\mathrm{a}}$ \\
Singha (S) & 86 & 100 & $93.2 \pm 12.0^{\mathrm{d}}$ \\
F1 (B x S) & 100 & 57 & $>116.6 \pm 14.3^{\mathrm{b}}$ \\
F2 (B x S) & 100 & 68 & $>108.0 \pm 15.2^{\mathrm{c}}$ \\
\hline
\end{tabular}

Note: Values for days to first open flower are the means \pm standard deviations; within a column, values followed by the same letters do not differ significantly $(\mathrm{P}<0.05)$.

\section{Experiment 2}

Again, soil disease resulted in the death of $50 \%$ of plants by 140 days after planting (first imbibition), with little difference in survival rate between genotypes (Table 4). The two Bogor plants that survived did not flower before termination of the experiment on day 165 (4 February 2107). There was no significant difference between mean flowering time for Singha and for the F1 hybrid plants. These two genotypes did not differ significantly in the duration of flowering, number of days to first pod, or the total number of flowers that opened up to termination of the experiment.

\section{Experiment 3}

All but one of the forty plants survived through to termination of Experiment 3 on day 133 (16 March 2017) (Table 5). There were no symptoms of collar-rot in these plants raised within the same nursery area as Experiment 1 and 2 but planted into a favorable soil mix in poly-bags rather than directly into the ground. By day 118 (1 March 2017), all plants of the Singha variety had opened at least one flower (with an average of 93 days to the first flower), while none of the Bogor plants produced a flower before day 127 after planting (10 March). The F1 and F2 plants were between the parental values in the average number of days to first flower, although not every plant had reached first open flower before termination on 16 March. On average, flowering was a little earlier in the F2 plants than the F1 plants.

When the flowering dates for the nineteen F2 plants were plotted out on a frequency histogram (Figure 3), there was indication of a discontinuity in the distribution, with a grouping of six F2 plants flowering before the average flowering date for the Singha variety, another grouping that overlapped the distribution for the F1 plants, and two late maturing F2 plants that resembled the Bogor parents in their flowering time. A Chi-squared test of fit suggested that the ratio of 6 early: 11 intermediate: 2 late-flowering F2 plants would be adequately explained by a single gene locus model with incomplete dominance (Chi-squared 
value of 2.16 with 2 degrees of freedom; $\mathrm{P}<0.05)$. Even if the two F2 plants with flowering dates between 96 and 104 days were classified in the early-flowering group, the adjusted ratio of 8 early: 9 intermediate: 2 late did not differ significantly from a 1:2:1 incomplete dominance model (Chi-squared value of 3.84). Nevertheless, because of the small number of F2 plants, care must be taken in accepting without reservation both the apparent discontinuity in the distribution of flowering time and the hypothesized major gene interpretation of its cause.

\section{Susceptibility to false-rust disease}

In Experiments 1 and 2, no symptoms were observed of the well-known false-rust disease of winged bean. But in Experiment 3, symptoms of this disease attributable to the fungal parasite Synchytrium psophocarpi (Rac.) Gaümann was first noticed on an F1 plant on day 93 (4 February 2017) and then appeared on many other plants over the succeeding weeks (Figure 4). The progress of the disease was followed until termination of the experiment on 16 March, on which date all plants of the Singha parent variety, six out of seven of the F1 plants, and thirteen out of nineteen F2 plants were affected by the disease. None of the Bogor parent plants showed symptoms of the disease.

False-rust caused by $S$. psophocarpi has been recorded as a significant disease of winged bean in Bogor since at least the end of the Nineteenth century (Raciborski 1898), but Aminah-Lubis (1980) and Aminah-Lubis and Sastrapradja (1981) observed genetically influenced resistance to the disease among winged bean germplasm in Bogor. This was confirmed by Thompson and Haryono (1979) and Parman and Thompson (1981) working with the Bogor germplasm in their investigations in Central Java.

The results of Experiment 3 add to this body of evidence. Susceptibility to false rust was dominant to resistance, with the F2 results (13: 6) conforming closely to a classic 3:1 ratio (Chi-squared test; $\mathrm{p}<0.05)$ indicative of a single gene effect with complete dominance for susceptibility. This is largely in agreement with the findings of the comprehensive investigation by AminahLubis and Sastrapradja (1981). Among some of their crosses, they too obtained a $3: 1$ ratio of susceptible to resistant F2 plants, but with other crosses, they obtained a 15:1 ratio of susceptible to resistant, indicative of a twogene model with duplicate dominant epistasis. As the authors explained, such a model would reduce to a $3: 1$ ratio in cases where the parents in the crosses only differed at one of the two gene loci.

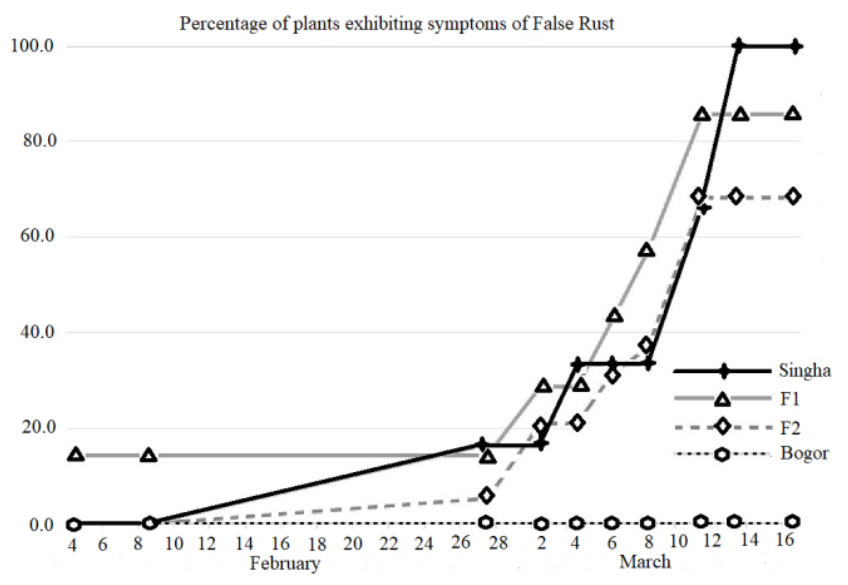

Figure 4. The percentage of plants of the Bogor and Singha varieties and their F1 and F2 hybrid offspring that exhibited symptoms of false-rust disease (Synchytrium psophocarpi (Rac.) Gaümann) on successive observation occasions up to final harvest in Experient 3.

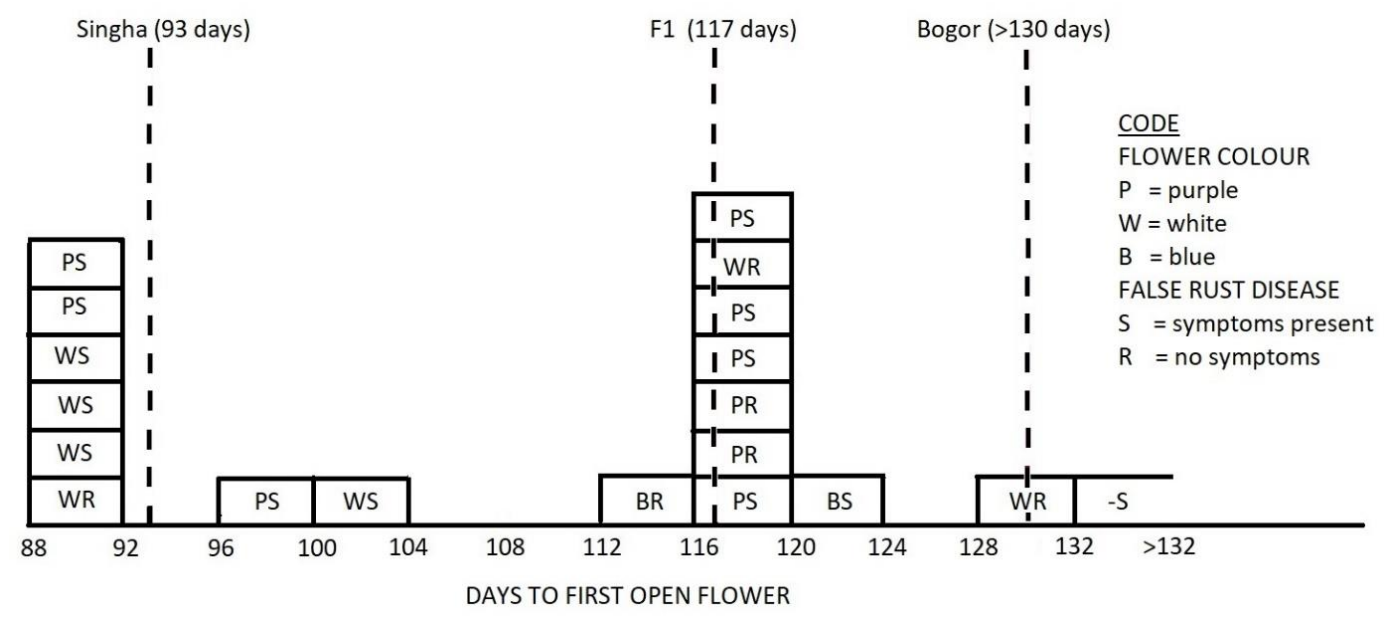

Figure 3. The frequency distribution for the number of days from planting to the first open flower among nineteen F2 plants. The vertical broken lines represent the mean values for the parental genotypes (Singha and Bogor) and for the F1 hybrids. The flower color (Purple, White or Blue) and the susceptibility to Synchytrium psophocarpi (Susceptible or Resistant) are identified for individual F2 plants in the distribution. The three characteristics - days to flowering, flower color, and susceptibility to $S$. psophocarpi - appeared to be distributed independently of one another, but this independence was not tested statistically, being beyond the scope of the inquiry. 


\section{Discussion}

Winged bean germplasm from Java is worthy of further study and conservation, especially as a source of resistance to diseases of economic importance (Thompson and Haryono 1979). There are few abiotic constraints on the growth of winged bean in Bogor. Rainfall and temperature vary little across the year, and both are at levels favorable to the growth of winged bean (Herath and Ormrod 1979; Wong and Schwabe 1980; Ruegg 1981; Schiavinato and Valio 1996). Furthermore, the volcanic soils of the Bogor environment are relatively fertile compared to many other soils of the high rainfall tropics. It is not surprising then to find that the varieties of winged been that have evolved in this environment are extravagant in their vegetative growth and in no haste to proceed into a reproductive phase. The environmental factors that promote vigorous growth also favor the growth of disease organisms and pests. A plant type that builds up its biomass before flower initiation and then spreads its flowering over an extended period is more likely to survive to produce viable offspring than one that rushes into reproduction at the expense of developing the vegetative reserves needed to sustain pod and seed development.

In 1978, a screening in Malaysia of 147 winged bean accessions from across the range of countries where the species had traditionally been grown (Table 6) revealed that a group of six accessions obtained from the Bogor collection of Sastrapradja et al. (1978) were the last of all accessions to mature (Eagleton 1983; Eagleton et al. 1985). The Bogor accessions had an indeterminate growth habit; thick, hardened stems with low branches that developed secondary roots from leaf nodes in contact with moist ground; and a late, sparse flowering pattern.

Table 6. The date to first open flower among 147 winged bean accessions planted in a randomized block design with two replicate plots (of 2-3 plants) per accession (in Serdang, Malaysia $\left(3^{0} \mathrm{~N}, 102^{\circ} \mathrm{E} ; 75 \mathrm{~m}\right.$ asl) on 14 December 1978 (Eagleton 1983).

\begin{tabular}{lccc}
\hline \multirow{2}{*}{$\begin{array}{c}\text { Origin of } \\
\text { accessions }\end{array}$} & \multirow{2}{*}{$\begin{array}{c}\text { Number } \\
\text { of } \\
\text { accessions }\end{array}$} & \multicolumn{2}{c}{$\begin{array}{c}\text { Number of days to first } \\
\text { open flower }\end{array}$} \\
\cline { 3 - 4 } & & Mean & $\begin{array}{c}\text { Standard } \\
\text { Error }\end{array}$ \\
\hline Papua New Guinea & 52 & 52.9 & 1.1 \\
Indonesia (Bogor) & 7 & $>111.2$ & 12.4 \\
Indonesia (Other) & 6 & $>74.0$ & 11.5 \\
Malaysia & 21 & 90.1 & 4.0 \\
Thailand & 44 & 83.1 & 3.5 \\
Miscellaneous & 17 & 68.3 & 4.3 \\
Total & 147 & $>72.7$ & 2.1 \\
\hline Not & &
\end{tabular}

Note: The Papua New Guinea accessions derived from collection trips described by Khan (1976); the Bogor accessions were from the collection of Sastrapradja et al. (1978); the other Indonesian accessions derived from collections of Thompson and Haryono (1979) and of G.A. de Neve; the Malaysian accessions were from a collection trip by the author along the west coast of peninsular Malaysia and a few from Wong (1980): the majority of the Thai accessions came from a collection trip made by Stern, Gypmantasiri and Thonguthaisri in northwestern Thailand in 1977 and a few from Chomchalow et al. (1980); the miscellaneous accessions were mainly from institutional collections in IITA in Nigeria, NBPGR in India, and the University of Peradeniya in Sri Lanka.
The investigation reported here supports these findings; the Bogor variety was not only very late in its flowering across all three planting occasions, but appeared more delayed in long daylengths (Figure 5). Many studies have demonstrated the sensitivity of winged bean phenology to daylength and temperature: short days (below 12 hours) and day/night temperatures of around $27^{\circ} / 23^{\circ} \mathrm{C}$ are optimal for inducing early flowering (Abe et al. 1988; Schiavinato and Valio 1996; Tanzi et al. 2019 a). In Bogor, at latitude $6^{0} \mathrm{~S}$, the day length does not vary much across the year. Nevertheless, in Experiment 2 when daylength was at its maximum, the Bogor plants failed to flower, whereas the Singha plants flowered in 83 days, compared with 80 days in Experiment 1 and 93 days in Experiment 3.

The F1 plants were earlier to flower than the Bogor variety in all three experiments, and in the first two experiments not significantly later to flower than plants of the Singha parent variety (Figure 5). The fact that the F2 segregating generation was at least as early to flower on average as the F1generation suggest that genetic progress could be made in introducing earliness into the Bogor genetic background.

In a seven parent, half-diallel genetic analysis of winged bean flowering time at Port Moresby in lowland Papua New Guinea (PNG), Erskine (1981) found that in the long daylengths of a December planting, the one Javanese accession included in the analysis was up to 30 days later to flower than four PNG parent accessions. Among the F1 arrays between the Javanese and PNG accessions, there was significant negative heterosis indicative of partial dominance for earliness of flowering. In the study reported here, earliness to flower in the F1 generation of the cross between Singha and Bogor also appeared partially dominant to lateness. In the PNG study, there was very little variation for flowering time among the parents and F2 arrays in the short daylengths of a July planting, in contrast to the large differences between parent accessions and significant variation among F2 plants observed in Experiment 3 in this study. In this study, there was evidence that a single gene locus might have been a predominant influence in the distribution of flowering time values among the F2 plants of the cross between Singha and Bogor. However, caution is required in accepting this inference because of the small number of plants in the study.

The mean time to first open flower in Port Moresby across the seven parent accessions included in the studies of Erskine (1980) and Erskine and Kesavan (1982) was 56.6 days, 47.7 days and 48.9 days for plantings in December, May and July respectively. Contrastingly, in Bogor, the mean number of days to first open flower for the Singha and Bogor accessions was 79.7 and 122.8 respectively, in Experiment 1; 82.8 and >165.0 in Experiment 2; and 93.2 and >130.3 in Experiment 3 . Clearly, there was more at play in the very late maturity of winged bean development in the Bogor environment than just photoperiod effects. The annual mean temperature in Port Moresby is $26.8^{\circ} \mathrm{C}$ compared with just $25.2^{\circ} \mathrm{C}$ in Bogor. Moreover, low natural light intensity and shade from surrounding trees in the Bogor trial site are likely to have been delaying factors in plant growth and phenological development in this study. 


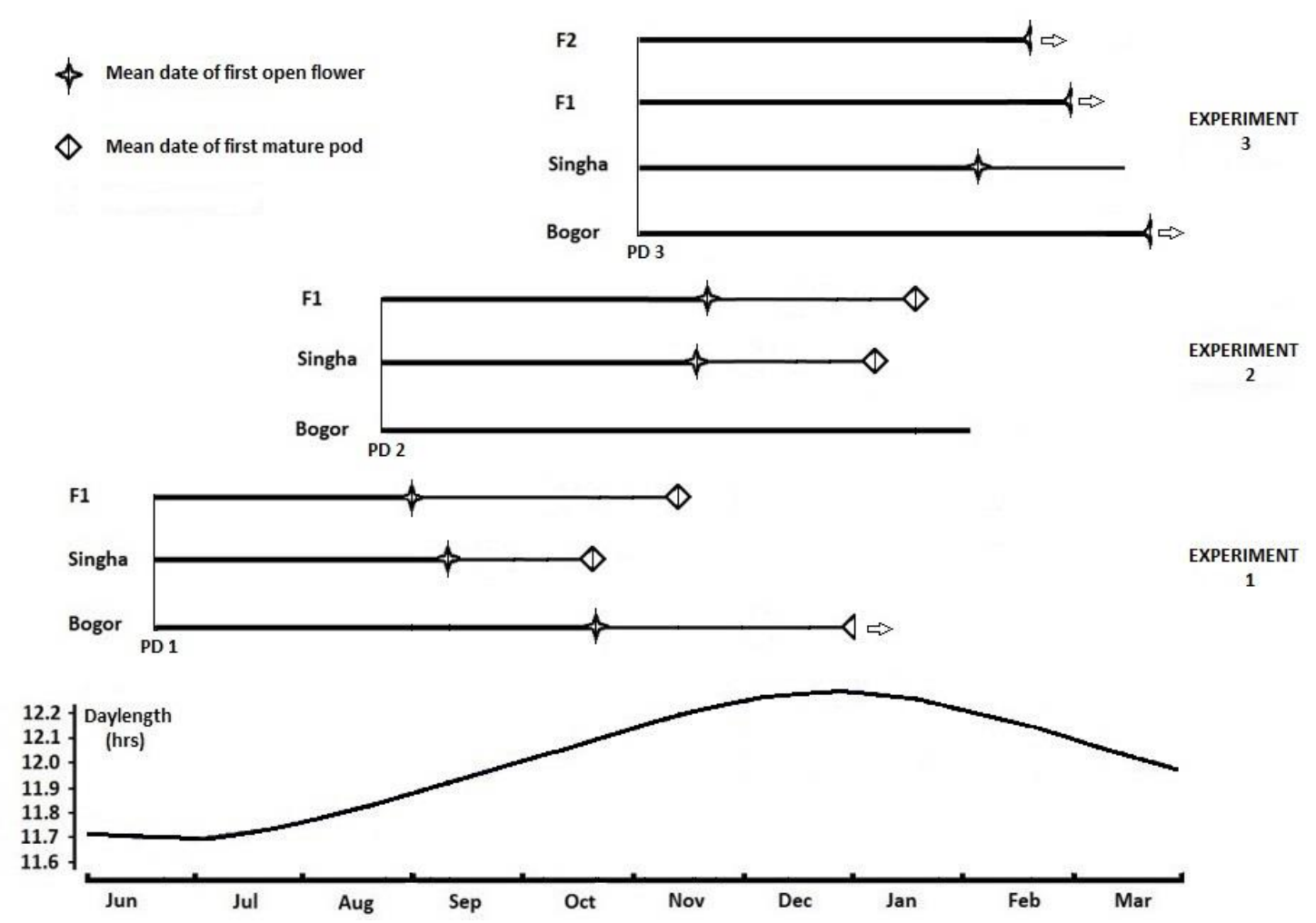

Figure 5. Summary of the phenological development of the Bogor and Singha varieties and their hybrid offspring in the three experiments in relation to variation in average daylength across the year in the Bogor environment. PD 1, PD 2 and PD 3 are the planting dates for the three experiments. Right pointing arrows shown for some phenological events indicate that at least one replicate plant had not achieved that phenological stage by the time the experiment was terminated, thus indicating the provisional status of the mean dates depicted for those phenological events.

The Bogor germplasm has characteristics that could be of use in plant breeding programs in other locations. Tanzi et al. (2019 b) have recently shown the advantages for vegetable pod production of the branching characteristic of late-maturing varieties. Also of interest, is the Bogor variety's strong resistance to false-rust.

False-rust caused by the host-specific, obligate endoparasite, Synchytrium psophocarpi (Rac.) Gaümann is of economic importance not only in Indonesia but also in the Philippines, Papua New Guinea and Malaysia (De Vera-Chaston 1977; Drinkall and Price 1979; Karami et al 2009). On current evidence, S. psophocarpi is hostspecific: despite attempts to induce infection on a wide range of potential leguminous and non-leguminous plant genera, winged bean has so far been the only species that could be artificially infected by the disease (Gaümann 1927; Drinkall and Price 1986). Not even the related African species, P. scandens (Endl.) Verdc., thriving in Bogor Botanic Gardens near the site of the current investigation (Rizmoon 2016), is susceptible to false-rust.

False-rust is visually striking (Drinkall and Price 1979, 1986) and the fact that it is not listed among the diseases of winged bean in Sri Lanka (Shanthichandra et al. 1990), where much agronomic research on winged bean was conducted in the 1980s, can be taken as evidence of its likely absence in that part of the world. In India, $S$. psophocarpi is not listed among more than 50 species of the genus Synchytrium recorded on a wide range of plant host species (Karling 1961, Reddy 2015 ). Based on similar lack of definitive sightings in the country reports of many authors who have worked with winged bean over the years, it seems reasonable to assume that this disease is absent from or rare in India, Myanmar, Vietnam, and most of Thailand, (Burkill 1906; Chomchalow et al. 1980; Rajendran et al. 1980; Taborsky 1981). There has been one suggestion of false-rust in Bangladesh (Haq et al. 1981) but no mention of the disease on winged bean in Mauritius (De Sornay 1916). Pospisil et al. (1971) recorded a possible sighting of false-rust on winged bean in Ghana, but Onesirosan's (1981) report of a severe outbreak in largescale plantings at Ilé-Ifè in the humid tropical zone of Nigeria is at odds with other reports for West Africa in which false-rust did not appear to be of any consequence (Karikari 1980; Ravelli et al. 1980; Fortuner et al. 1979; Nangju and Baudoin 1979; Sinnadurai and Nyalemegbe 1979). 

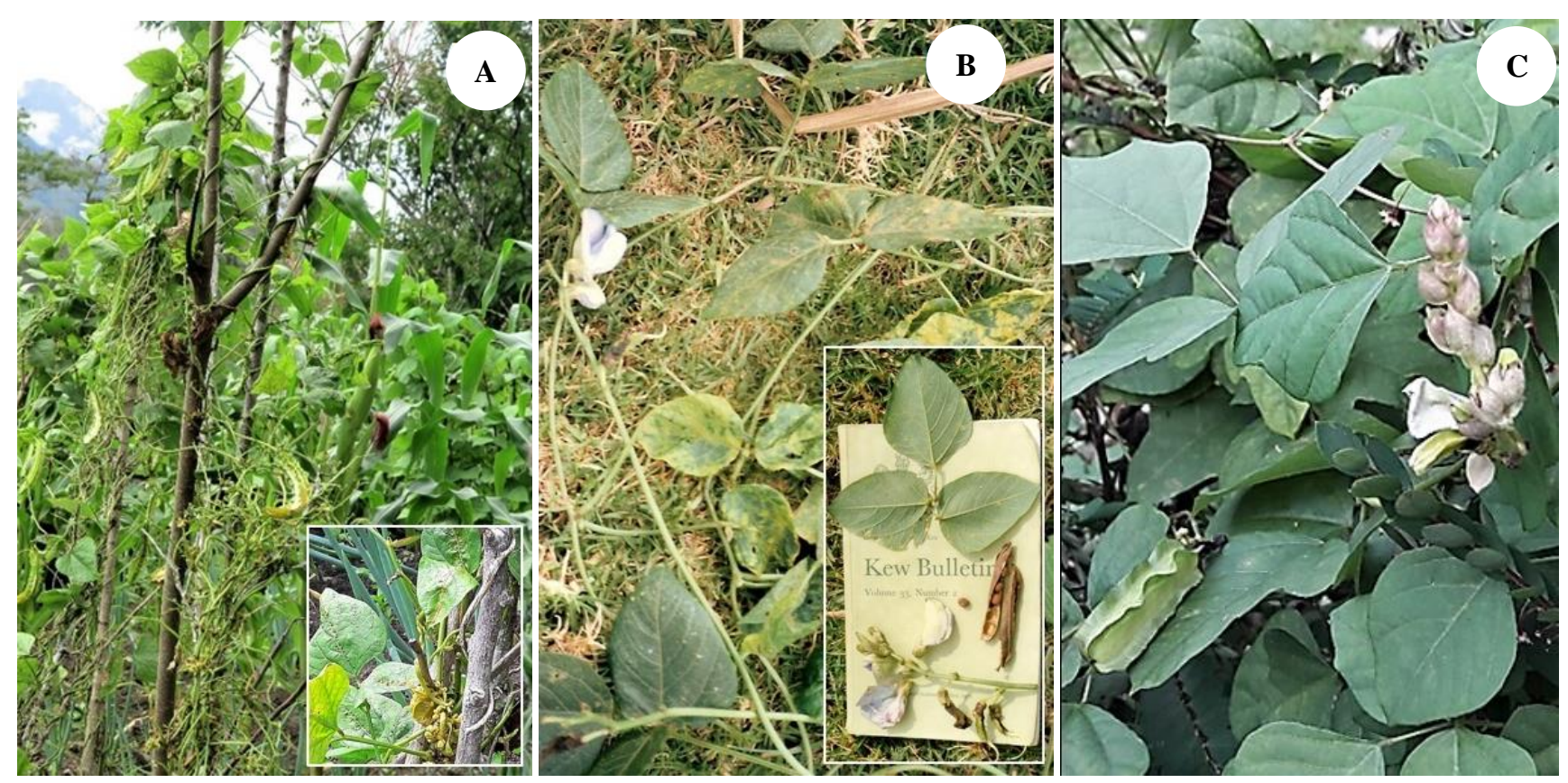

Figure 6. Psophocarpus species and false-rust. From left to right (A) An early maturing winged bean (P. tetragonolobus) variety in Wamena, Indonesia (inset shows heavy infection by false-rust disease (Synchytrium psophocarpi)), (B) P. grandiflorus at Lake Bunyonyi, Uganda, with leaves exhibiting symptoms that resemble false-rust, (C) Perennial P. scandens in Bogor Botanic Gardens with no sign of false-rust (see Rizmoon 2016)

The absence of definitive records of Synchytrium psophocarpi (Rac.) Gaümann from winged bean domesticates in Africa and the western periphery of the Indian Ocean is intriguing. In Zaire (Harder et al. 1990; Harder and Smartt 1992), observed what appeared to be false-rust on the related species Psophocarpus grandiflorus Wilczek. In western Uganda and Ethiopia, Eagleton and Mengistu (1988, unpublished data) also observed orange galls resembling false-rust on $P$. grandiflorus (see Figure 6). The orange galls sampled from herbarium specimens of the Ugandan $P$. grandiflorus were tentatively identified as having arisen from $S$. psophocarpi by Dr T. V. Price, and by $\mathrm{Dr} \mathrm{G}$. Hall of the CAB International Mycological Institute. However, Synchytrium DeBary and Woronin 1863 is a large genus of fungi with many plant hosts (Karling 1964). It remains to be seen whether the falserusts found on winged bean and $P$. grandiflorus are one and the same organism; an issue which has implications for the question of winged bean origins (Fatihah et al. 2012; Yang et al. 2018). A way of testing this would be to attempt to infect growing plants of $P$. grandiflorus with viable false-rust sporangia derived from $P$. tetragonolobus, and vice versa. A model for this kind of investigation is the experiment of Drinkall and Price (1986) in Papua New Guinea, who inoculated winged bean with zoospores of Synchytrium minutum (Pat.) Gaümann taken from leaves of the legume species Pueraria lobata (Wild) Ohwi. They found that the infection failed to develop on the winged bean. Modern molecular techniques could also shed light on this issue.
Although Synchytrium psophocarpi is the most obvious disease of winged bean in island South-East Asia and Melanesia, the devastation caused by various root- and collar-rot organisms is often of greater consequence in situations where winged bean is planted on water-logged or wet compact soil types. In Papua New Guinea, Price and Munro (1978) reported that fungal pathogens such as a Rhizoctonia solani J.G. Kühn, Fusarium semitectum Berk. \& Ravenel, Fusarium equiseti (Corda) Sacc., Fusarium moniliforme J. Sheld. and Macrophomina phaseolina (Tassi) Goid. are at times responsible for seedling mortality of up to $40-50 \%$. Similarly, in Sri Lanka, Shanthichandra et al. (1990) isolated Rhizoctonia solani, Fusarium solani (Mart.) Sacc. and Neonectria obtusispora (Cooke \& Harkn.) from collar-rot in winged bean: "the isolates were pathogenic singly, and highly pathogenic in combination". The pathogenicity of collar-rot fungi is related to soil type, depth of sowing and inoculum density, such that shallow planting in well-drained soils is recommended to control infections (Shanthichandra et al. 1990; Reddy 2015). Identification of winged bean genotypes with resistance to root- and collar-rot disease organisms should be a priority for plant breeding programs in humid tropical environments. In the first instance, the most efficient approach to this end would be to screen a wide range of germplasm for the ability to grow on compacted, waterlogged soils of the type experienced in this experiment. Only after such screening, would it make sense to proceed to a detailed evaluation of genotypic resistance to specific soil-borne pathogens. 
In conclusion, winged bean varieties adapted to the moist equatorial climate and volcanic-derived soils of West Java experience few abiotic constraints to growth. However, these are the very conditions that favor the propagation of would-be pests and diseases. As a result, the local varieties have evolved tendencies to luxuriant vegetative growth; delayed, dispersed, flowering; and genetically determined resistance to local pathogens. The investigation reported here has shown that it should be possible to develop early maturing varieties useful to vegetable growers in West Java by out-crossing the local Bogor variety to early maturing accessions. Careful selection in the segregating generations of such crosses would aim to produce lines that combine early maturity along with the Bogor variety's longevity and resistance to false-rust disease. Further investigations are required among a broader range of germplasm to identify winged bean genotypes that could be used in plant breeding programs to develop varieties with resistance to root- and collar-rot diseases.

\section{ACKNOWLEDGEMENTS}

The author is grateful to the Centre for Plant Conservation Bogor Botanic Gardens for the provision of land for this investigation and for facilitating its implementation. Gratitude is also extended to the Australian Volunteer Program (AVP) for all the support given during the author's two-year assignment in the Gardens. The insightful comments of the anonymous reviewers encouraged the author to more thoroughly interrogate the reported data and improve its presentation; thank you.

\section{REFERENCES}

Abe J, Nakamura H, Hanada T, Shimamoto Y, Nakata D. 1988. Response of winged bean to temperature and photoperiod at different locations from the tropics to the temperate zone. JARQ 21 (4): 308-313.

Aminah-Lubis SH. 1980. Flowering behavior of the winged bean. In: The Winged Bean. Papers presented in the 1st International Symposium on Developing the Potentials of the Winged Bean, January 1978, Manila. Philippine Council for Agriculture Resources Research, Los Baños, Laguna, Philippines. pp. 121-123.

Aminah-Lubis SH, Sastrapradja DS. 1981. Susceptibility of the winged bean varieties to Synchytrium psophocarpi (Rac.) Gaümann. 6 pp. Unpublished paper presented in the 2nd International Symposium on Developing the Potentials of the Winged Bean, Colombo, Sri Lanka, January 1981. Abstracted in The Winged Bean Flyer (Agricultural Information Bank for Asia, Laguna, Philippines) 3 (2): 28.

Burkill IH. 1906. Goa beans in India. Agricultural Ledger 4: 101-114.

Climate-Data 2019. Climate Bogor. https:/en.climatedata.org/asia/indonesia/west-java/bogor-3930/ (access 18/08/2019).

Benjamini Y, Hochberg Y. 1995. Controlling the false discovery rate: a practical and powerful approach to multiple testing. J Royal Statist Soc Ser B. 57 (1): 289-300.

Chomchalow N, Suputtitada S, Peyachoknagul S. 1980. Genetic diversity of winged bean in Thailand: a preliminary report. In: The Winged Bean. Papers presented in the 1st International Symposium on Developing the Potentials of the Winged Bean, January 1978, Manila. Philippine Council for Agriculture Resources Research, Los Baños, Laguna, Philippines.

De Sornay P. 1916. Psophocarpus tetragonolobus (Pois Carré). In: Green Manures and Manuring in the Tropics, Including an Account of the
Economic Value of Leguminosae as Sources of Foodstuffs, Vegetable Oils, Drug, \&C. John Bole, Sons and Danielson Ltd., London.

De Vera-Chaston HP. 1977. Synchytrium psophocarpi (Rac.) Gaümann, its development and anatomy of infection on Psophocarpus tetragonolobus (L.) DC. Kalikasan, Philippine J Biol 6 (3): 183-198.

Drinkall MJ, Price TV. 1979. Studies on Synchytrium psophocarpi on winged bean in Papua New Guinea. Trans Br Mycol Soc 72: 91-98. DOI: 10.1016/S0007-1536 (79)80012-1

Drinkall MJ, Price TV. 1986. Studies on the infection of the winged bean by Synchytrium psophocarpi in Papua New Guinea. Ann Appl Biol 109: 87-94. DOI: 10.1111/j.1744-7348.1986.tb03186.x

Eagleton GE. 1983. Evaluation of genetic resources in the winged bean (Psophocarpus tetragonolobus (L.) DC.) and their utilisation in the development of cultivars for higher latitudes. [Dissertation], University of Western Australia, Perth.

Eagleton GE, Khan TN, Erskine W. 1985. Winged Bean (Psophocarpus tetragonolobus (L.) DC.). In: Summerfield RJ, Roberts EJ (eds.). Grain Legume Crops. Collins, London.

Erskine W. 1981. The heritability and combining ability of vegetative and phenological characters of winged bean (Psophocarpus tetragonolobus (L.) D.C.). J Agric Sci Camb 96: 503-509.

Erskine W, Bala AA. 1976. Crossing technique in winged bean. Trop Grain Legume Bull 6: 32-35.

Erskine W, Kesavan V. 1982. Genetic variability in the green pod production of winged bean. J Horticultural Science 57: 209-213.

Fatihah NHN, Maxted N, Rico Arce L. 2012. Cladistic analysis of Psophocarpus Neck. ex DC. (Leguminosae, Papilionoideae) based on morphological characters. S A J Bot 83: 78-88. DOI: 10.1016/j.sajb.2012.07.010

Fortuner R, Fauquet C, Lourd M. 1979. Diseases of the winged bean in Ivory Coast. Plant Dis Rep 63 (3): 194-199.

Gaümann EA. 1927. Mykologische Mitteilungen III. Annales Mycolgici 25: 165-177.

Haq N, Chowdhury SU and Rashid M. 1981. Germplasm resources of winged bean in Bangladesh. 13 pp. Unpublished paper presented in the 2nd International Symposium on Developing the Potentials of the Winged Bean, Colombo, Sri Lanka, January 1981. Abstracted in The Winged Bean Flyer (Agricultural Information Bank for Asia, Laguna, Philippines) 3 (2): 10-11.

Harder D, Onyembe PML, Musasa T. 1990. Uses, nutritional composition, and ecogeography of four species of Psophocarpus (Fabaceae, Phaseoleae) in Zaire. Econ Bot 44 (3): 391-409. DOI: 10.1007/BF03183924

Harder DK, Smartt J. 1992. Further evidence on the origin of the cultivated winged bean, Psophocarpus tetragonolobus (L.) DC. (Fabaceae): chromosome numbers and the presence of a host-specific fungus. Econ Bot 46 (2): 187-191. DOI: 10.1007/BF02930637

Herath HMW, Ormrod DP. 1979. Effects of temperature and photoperiod on winged beans (Psophocarpus tetragonolobus (L.) D.C.). Ann Bot 43 (6): 729-736. DOI: 10.1093/oxfordjournals.aob.a085686

Karami A, Ahmad ZAM, Sijam K. 2009. Morphological characteristics and pathogenicity of Synchytrium psophocarpi (Rac.) Baumann. Am J Appl Sci 6 (11): 1876-1879. DOI: 10.3844/ajassp.2009.1876.1879

Karikari SK. 1980. An integrated approach toward agronomic and other research needs on winged bean: a case study of winged bean collaborative program in Ghana. In: The Winged Bean. The 1st International Symposium on Developing the Potentials of the Winged Bean, January 1978, Manila. Philippine Council for Agriculture Resources Research, Los Baños, Laguna, Philippines.

Karling JS. 1961. Indian species of Synchytrium. Sydowia 15: 26-44.

Karling JS. 1964. Synchytrium. Academic Press, New York.

Khan TN. 1976. Papua New Guinea: a centre of genetic diversity in winged bean (Psophocarpus tetragonolobus (L.) DC.). Euphytica 25: 693-706.

Khan TN. 1992. Psophocarpus tetragonolobus (L.) DC. In: Siemonsma JS, Kasem Piluek (eds) Plant Resources of South-East Asia No 8. Vegetables. PROSEA Foundation, Bogor, Indonesia.

Lepcha P, Egan AN, Doyle JJ, Sathyanarayana N. 2017. A review on current status and future prospects of winged bean (Psophocarpus tetragonolobus) in tropical agriculture. Plant Foods Hum Nutr 72: 225-235. DOI: $10.1007 / \mathrm{s} 1113$ 0-017-0627-0

Nangju D and Baudoin JP. 1979. Performance of winged bean (Psophocarpus tetragonolobus (L.) DC.) in Nigeria. J Hort Sci 54 (2): 129-136. DOI: 10.1080/00221 589.1979.11514860 
Onesirosan PT. 1981. Diseases of the winged bean in Southern Nigeria. The 2nd International Symposium on Developing the Potentials of the Winged Bean, Colombo, Sri Lanka, January 1981.

Parman, Thompson AE. 1981. Resistance to false rust in winged beans. Hort Sci 16: 63-65

Pospisil F, Karikari SK, Boemah-Mensah E. 1971. Investigations of winged bean in Ghana. World Crops 23: 260-264.

Price TV, Munro PE. 1978. Fungi associated with collar rot of winged bean in Papua New Guinea. Proc Natl Acad Sci USA 24 (1): 53-56. DOI: $10.1080 / 09670877809414258$

Raciborski M. 1898. Pflanzenpathologisches aus Java. Pflanzenkrankheiten 8: 195-200.

Rajendran R, Satyanarayana A, Selvaraj Y, Bhargava BS. 1980. Some investigations on the indigenous and exotic collection of winged bean in India. In: The Winged Bean. The 1st International Symposium on Developing the Potentials of the Winged Bean, January 1978, Manila. Philippine Council for Agriculture Resources Research, Los Baños, Laguna, Philippines.

Ravelli GP, N'Zi GK, Diaby L, N'Dri KB, Mayer CG, Sylla BS. 1980. The winged bean as a new source of protein for rural populations in the Ivory Coast, West Africa. In: The Winged Bean. Papers presented. The 1st International Symposium on Developing the Potentials of the Winged Bean, January 1978, Manila. Philippine Council for Agriculture Resources Research, Los Baños, Laguna, Philippines.

Reddy PP. 2015. Plant Protection in Tropical Root and Tuber Crops. Springer, New Delhi.

Rizmoon NZ. 2016. Mengenal the winged bean (Psophocarpus scandens (Endl.) Verdc.) Warta Kebun Raya 14 (2): 27-32. [Indonesian]

Rüegg J. 1981. Effects of temperature and water stress on the growth and yield of winged bean (Psophocarpus tetragonolobus (L.) DC.). J Hort Sci 56: 331-338. DOI: 10.1080/00221 589.1981.11515 009

Sastrapradja S, Aminah-Lubis SH. 1975. Psophocarpus tetragonolobus as a minor garden vegetable in Java. In: Southeast Asian Plant Genetic Resources. Proceedings of a symposium sponsored by the International Board for Plant Genetic Resources, Bogor, Indonesia.

Sastrapradja S, Aminah-Lubis SH, Lubis I, Sastrapradja D. 1978. A survey of variation in Psophocarpus tetragonolobus (L.) DC. with reference to the Javanese samples. Annales Bogorienses 6 (4): 221 230 .

Schiavinato MA, Valio IFM. 1996. Influence of photoperiod and temperature on the development of winged bean plants. R Bras Fisiol Veg 8 (2): 105-110.
Shanthichandra WKN, Gunasekera SA, Price TV. 1990. Diseases and pests of the winged bean (Psophocarpus tetragonolobus (L.) DC.) in Sri Lanka. Trop Pest Manag 36 (4): 375-379. DOI: 10.1080/09670879009371515

Sinnadurai S, Nyalemegbe KD. 1979. Effect of photoperiod on the nodulation, flowering and seed yield of winged bean (Psophocarpus tetragonolobus (L.) DC.). Ghana J Agric Sci 12: 27-30.

Taborsky V. 1981. Diseases and pests of winged bean in Vietnam. The 2nd International Symposium on Developing the Potentials of the Winged Bean, Colombo, Sri Lanka, January 1981.

Tanzi AS, Eagleton GE, Ho WK, Wong QN, Mayes S, Massawe F. 2019a. Winged bean (Psophocarpus tetragonolobus (L.) DC.) for food and nutritional security: synthesis of past research and future direction. Planta 250 (3): 911-931. DOI: 10.1007/s00425-019-031412

Tanzi AS, Ho WK, Massawe F, Mayes S. 2019b. Development and interaction between plant architecture and yield-related traits in winged bean (Psophocarpus tetragonolobus (L.) DC.). Euphytica 215: 36. DOI: $10.1007 / \mathrm{s} 10681-019-2359-8$

Thompson AE, Haryono SK. 1979. Sources of resistance to two important diseases of winged bean, Psophocarpus tetragonolobus (L.) DC. Hort Sci 14 (4): 532-533.

Thompson AE, Haryono SK. 1980. Winged bean: unexploited tropical food crop. Hort Sci 15 (3): 233-238.

Wong KC. 1980. Agronomy of the winged bean in Malaysia. In: The Winged Bean. Papers presented in the 1st International Symposium on Developing the Potentials of the Winged Bean, January 1978, Manila. Philippine Council for Agriculture Resources Research, Los Baños, Laguna, Philippines.

Wong KC, Schwabe WW. 1980. Effects of daylength and day/night temperature on the growth, flowering and tuber formation of winged bean (Psophocarpus tetragonolobus (L.) DC.). In: Proceedings of Legumes in the Tropics. Universiti Pertanian Malaysia, Selangor, Malaysia.

Wong QN, Tanzi AS, Ho WK, Malla S, Blythe M, Karunaratne A, Massawe F, Mayes S. 2017. Development of gene-based SSR markers in winged bean (Psophocarpus tetragonolobus (L.) DC.) for diversity assessment. Genes 8: 100. DOI: 10.3390/genes 8030100

Yang SY, Grall A, Chapman MA. 2018. Origin and diversification of winged bean (Psophocarpus tetragonolobus (L.) DC.), a multipurpose underutilized legume. Am J Bot 105 (5): 888-897. DOI: 10.1002/ajb2.1093 